\title{
Sketches from the history of psychiatry
}

\section{A lesson from the history of psychiatry: competitive tendering for services and defective central heating systems in Georgian New Bethlem}

\author{
ROBERT HowARD, Registrar, The Maudsley Hospital, Denmark Hill, London SE5 8AZ
}

Entries in the minute books of the New Bethlem Hospital Building Committee from 1813-1816 contain details of the commissioning, installation and subsequent extensive modification of a system for heating the hospital. The system adopted was chosen principally for its cheapness, but in a manner that may seem familiar in the current climate of competitive tendering, with adoption of the cheapest proposal; through the incompetence of its manufacturer it was to prove problematic and dangerous.

The third Bethlem Hospital at St George's Fields in Lambeth (now the Imperial War Museum) opened its doors to patients in 1815. The previous hospital, built at Moorfields in 1676, had been heated by stoves in 'warming rooms', there being no provision for heating in the galleries or patients' cells. Those patients unable, or too unco-operative, to be taken from their cells to the warming rooms had consequently suffered greatly from the cold as the windows of their cells were unglazed.

When the New Hospital Building Committee met at Bridewell Hospital on 27 October 1813, it appears they had not given the subject of heating the new hospital much thought. On this day, however, they received a letter from William Slark and Son of Cheapside, offering to undertake the contract for

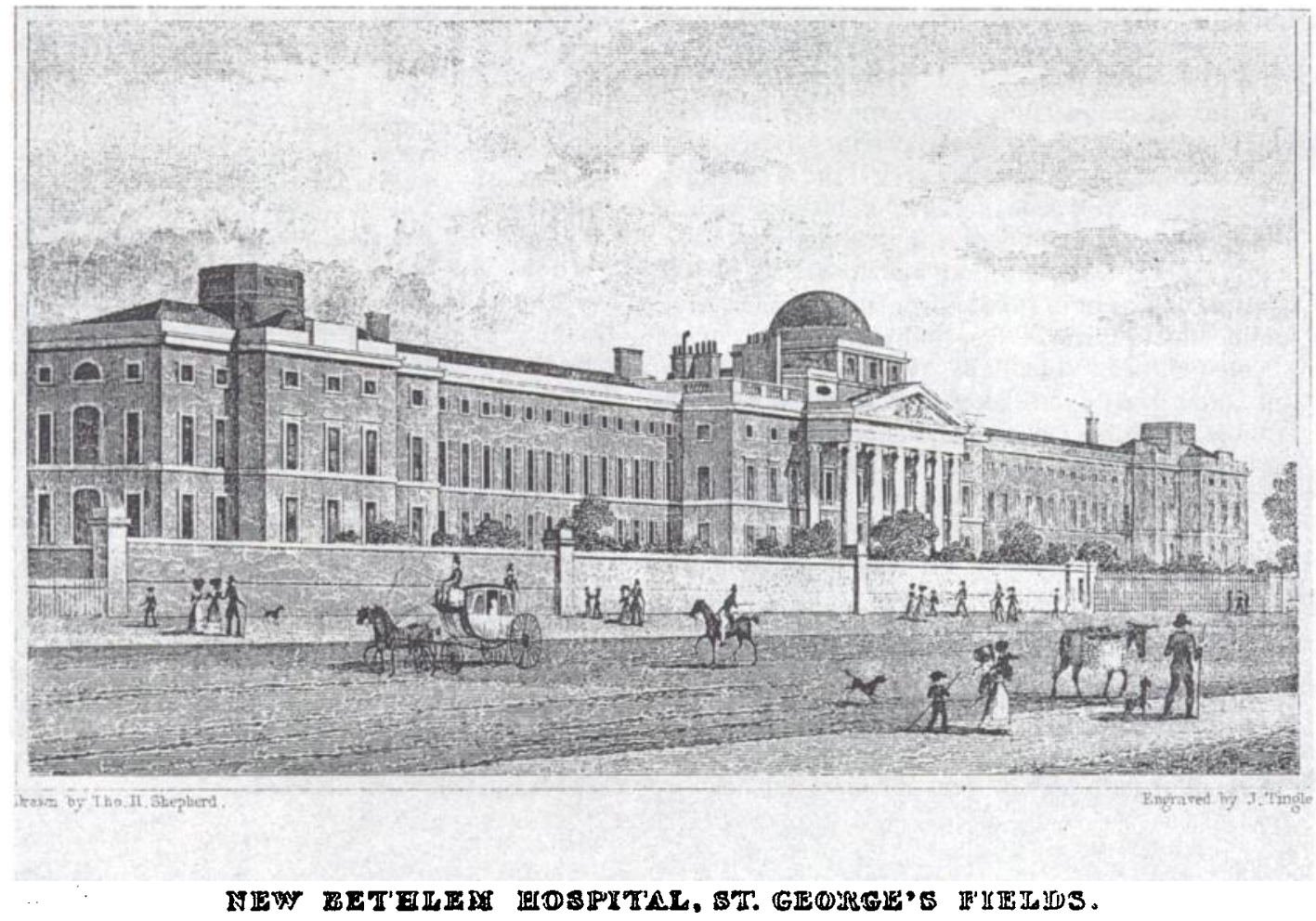


installation of a system for heating the hospital by steam, this being "the most wholesome, safe and economical manner of warming a Building of such magnitude, and at the same time inhabited by persons in that unhappy situation, which renders the usual mode of open fireplaces, or even closed stoves, not only unsafe but ineffectual".

The subject was referred to the hospital surveyor, who arranged to tour the Establishment for the Deaf and Dumb, where Mr Slark had already installed one of his steam systems. This demonstration failed to impress, and on 27 April 1814 the committee had still not chosen a heating system for the hospital. The surveyor was asked to advertise for alternative proposals, and to present these to the committee, together with their comparative costs. By November, the surveyor announced that as well as having toured the Naval, Military and Female Asylums, and various hospitals and philanthropic institutions, he had also collected and inspected eight different proposals for the new hospital's heating system. He reported on each in detail to the committee. Four of the proposals involved steam systems, by which steam generated in coal-fired boilers was used to heat and drive air through a closed system of pipes and 'steam boxes' which acted as radiators. Of the remaining four plans, all of which utilised air rather than steam systems, two were little more than collections of stoves strategically placed around the hospital, one involved digging up the floors to install a hypocaust system, and that of Mr Deacon of the Aeolian Office, Red Lion Square, consisted of an enormous stove, connected to a bellows machine, which he called the Aeolian, to pump hot air around the hospital.

All but three of the eight plans were dismissed because it was not felt they would be capable of heating the entire hospital. The committee expressed doubts about the efficacy of the Aeolian in particular. They were left with Mr Walker's two boiler steam system $(£ 1,360)$, Mr Mainwaring's hot air system $(£ 1,520)$, and $\mathrm{Mr}$ Thomas Deakin of Ludgate Hill and St John's Street's 'steam apparatus' which guaranteed to provide heat for cooking, washing, drying and warmth in the hospital for only $£ 986$.

Although they had no experience of equipping any similar establishment with a heating system, $\mathbf{M r}$ Deakin and his company had so greatly impressed the surveyor with their claims that they could heat every part of the hospital, even the upper galleries, that he was to enthuse, "The obstacles that appear so many and insurmountable to others, by him are not in the least regarded".

It seems to have been the economy of his estimate that won him the contract. This was particularly praised by the committee who recorded that the estimate left "nothing doubtful or uncertain".

Sadly, doubt and uncertainty are perhaps the most appropriate words to choose to describe the progress of $\mathrm{Mr}$ Deakin and his steam apparatus. As soon as he was awarded the contract, he changed the design of the heating system. It was, he suggested, probably advisable to have two boilers rather than the one he had initially proposed in case one became "disordered". This would of course cost more, but he was sure he could reduce the cost by removing the heating system he had planned for the upper floor day and warming rooms, and replacing it with simple extensions of the steam-carrying tubes and air drains that heated the basement. He gave a revised detailed breakdown of the total cost, which had now risen to $£ 1,113$ (Table I).

The hospital agreed in February 1815 to pay Deakin $£ 1,113$ for the installation, on the condition that he guaranteed the system against repairs for ten years, that all work on it was completed by 1 May, and that he furnished two securities bound to the sum of $£ 1,000$.

On 14 December 1815, the governors inspected Deakin's efforts, and concluded, "at present the apparatus is altogether incomplete".

An outside expert on heating systems, Professor Brand, was called in. He reported oozing of steam

TABLE I

Thomas Deakin's revised quote

Steam Boiler with Appendages

To heat the basement story according to plan and description with regulating cistern, condensed water pipes forming drains - heating also the 16 day and warming rooms with everything necessary to complete the operation and reinstating what works may be disturbed by its application

Copper and house for linen and 2 double steam boilers for provisions and steamers for potatoes complete $\quad 142$

Additional steam boilers as proposed

Tank as proposed to preserve the distilled water for washing, for medicinal, or other purposes, including pump (if adopted)

To apply the steam to dry linen, blankets \& $\mathrm{Co}$, 
and water from the joints of the steam pipes, and that Deakin had "committed the radical error of having no returning pipes" in the system. Deakin hurriedly corrected these defects, and Professor Brand pronounced himself satisfied that the apparatus would keep the hospital temperature at the recommended $55^{\circ} \mathrm{F}$. The apothecary, male and female keepers were instructed to measure the temperature around the hospital every two hours; and after a fortnight of such recording, the committee accepted that with the exception of some of the basement rooms which were too hot, the apparatus worked well. Deakin was requested to place guards around the steam boxes in the galleries to protect the patients from burning themselves. Continuous monitoring of the temperatures around the hospital by the apothecary and keepers was showing satisfactory levels. However, a new and alarming complication of Mr Deakin's steam apparatus emerged. The boiler flues that passed up the walls of the stock and waiting rooms had been fixed to the wall directly over pieces of structural timberwork. A consequence of this was that when the steam apparatus was in operation, "an emission of woodsmoke is perceptible", causing the steward "some apprehension for the safety of the building", as he reported to the building committee. Deakin was hastily recalled to change the route of his flues.

There are no further references in the building committee minutes to Mr Deakin or his steam apparatus, so we must assume that, to the amazement of everybody involved, it appeared to function well. For those who have been in the past, or may be currently, involved in the planning of new hospitals, the exploits of $\mathrm{Mr}$ Deakin and his heating company may strike a familiar chord. If there is a lesson to be learnt for the future, it must surely be that cheapest is not necessarily best!

\title{
The times
}

\section{Who owns money?}

\author{
M. R. Eastwood, Professor of Psychiatry, Clarke Institute of Psychiatry, \\ 250 College Street, Toronto, Ontario M5T 1R8, Canada
}

In my medical year there was a student who had been in the RAF in World War II. After the war he worked for Beaverbrook and the Express newspapers and went on to become a publisher. He studied medicine, while a publisher, and then came the crunch. To be a publisher or a doctor? On the first day of house jobs he inadvertently drove his Jaguar into the consultant's reserved parking spot, which caused no amusement. To add to his disquiet he found that his salary of $£ 35$ per month, after income tax, and then surtax on top, only paid for his pipe tobacco and refreshments. The rest of us were less egregious and embarked upon life with even less fiscal fun. A bottle of Woodpecker Cider on Saturday night was nirvana. Was this really the reward for all that education? (Most specialists had at least 28 years of formal education: from starting at age four to leaving postgraduate school.) Like many before me, particularly Edinburgh graduates, I crossed the high seas, at the age of 32. My naval forebears would have been surprised that it took so long, especially my father, who went to sea at 14 in World War I. There were many surprises, not least of which was that of money. In a career sojourn, from the UK to Australia and finally Canada, over 18 months, there was a tenfold increase in income.

Was it all worth it? Hard to say in the light of the astonishing financial changes of the last 20 years. In North America, while salaries have increased, the real value has not, due to inflation, but the distribution of wealth around the world certainly has. Ambitious doctors in Western Europe, North America and Australasia may now earn similar amounts of money. Private practice, government service and academia nestle alongside each other, albeit often uneasily, in all western jurisdictions. Moreover, there is comparability. At a conference breakfast recently in Rome, several of us contrasted incomes. It was clear that around $\$ 70,000$ to $\$ 80,000$, be it US, Canadian or Australian, or whatever currency multiple, was what academics earned around the world. With little difficulty North 